\title{
Conteúdos Jornalísticos nas Redes Sociais: o cenário das transmissões ao vivo no Facebook em Campo Grande, MS
}

\author{
Journalistic Content in Social Networks: the scenario of live broadcasts on Face- \\ book in Campo Grande, MS
}

\section{Contenidos Periodísticos en las Redes Sociales: el escenario de las transmisiones en vivo en el Facebook en Campo Grande, MS}

\author{
Oswaldo Ribeiro da Silva ${ }^{1}$ \\ Marcelo Vicente Cancio Soares ${ }^{1}$
}

Recebido em 30/10/2018; revisado e aprovado em 28/03/2019; aceito em 28/04/2019 DOI: http://dx.doi.org/10.20435/inter.v20i4.2209

\begin{abstract}
Resumo: Este trabalho analisa o cenário das transmissões ao vivo de conteúdos jornalísticos no Facebook em Campo Grande, MS. Para isso, foram avaliados o CBN Campo Grande, da FM 93,7, e o Jornal da Tarde, da TV O Estado MS-OE10. Como resultados preliminares do processo, ainda recente na imprensa local, o destaque é o uso do potencial de alcance das redes sociais, que esbarra em características do DNA da transmissão ao vivo e não se utiliza de recursos de interatividade na relação com os ouvintes/telespectadores/usuários dos conteúdos.
\end{abstract}

Palavras-chave: Jornalismo; conteúdos jornalísticos; redes sociais; transmissão ao vivo; Facebook.

Abstract: This paper analyzes the scenario of live broadcasts of journalistic content on Facebook in Campo Grande, MS. For that, CBN Campo Grande, from FM 93.7, and Jornal da Tarde, from TV O Estado MS-OE10, were evaluated. As preliminary results of the process, still recent in the local press, the highlight is the use of the reach potential of social networks, which runs against the characteristics of the DNA of the live transmission and does not use interactivity resources in the relation with the listeners/viewers/users of the content.

Keywords: Journalism; journalistic contents; social networks; live broadcast; Facebook.

Resumen: Este trabajo analiza el escenario de las transmisiones en vivo de contenidos periodísticos en Facebook en Campo Grande, MS. Para ello se evaluaron el CBN Campo Grande, de la FM 93,7, y el Jornal da Tarde, de la TV O Estado MS-OE10. Como resultados preliminares del proceso, aún reciente en la prensa local, el destaque es el uso del potencial de alcance de las redes sociales, que choca en características del ADN de la transmisión en vivo y no utiliza recursos de interactividad en la relación con los oyentes/ espectadores/ usuarios de los contenidos.

Palabras claves: Periodismo; contenidos periodísticos; redes sociales; transmisión en vivo; Facebook.

\section{INTRODUÇÃO}

As emissoras de televisão, desde a invenção e implantação, sempre foram as detentoras das transmissões ao vivo de conteúdos audiovisuais. Com a digitalização do processo de captação de imagens e sons, as possibilidades mudaram. Por conta disso, a informática em rede começou a oferecer a opção de compartilhamento de conteúdos audiovisuais gravados e, posteriormente, com as webcams, as transmissões ao vivo viraram uma realidade entre os usuários com estes equipamentos instalados nos desktops ou notebooks.

Nas redes sociais, as transmissões ao vivo de conteúdos audiovisuais aguardaram as mudanças tecnológicas e as ferramentas necessárias para se tornarem febre entre os usuários. Atualmente, redes sociais como Twitter, YouTube, Facebook, Instagram e WhatsApp oferecem facilidades para este tipo de compartilhamento de conteúdo, entre tantos outros.

1 Universidade Federal de Mato Grosso do Sul (UFMS), Campo Grande, Mato Grosso do Sul, Brasil. 
As emissoras de televisão internacionais, nacionais e regionais não perderam tempo e começaram a utilizar esta ferramenta como forma de ampliar o alcance das transmissões ao vivo, naturalmente levando em conta as relações contratuais com as redes sociais, bem como características de legislação próprias das empresas televisivas. Em nível local, dois exemplos podem ser citados: a Rádio CBN e a TV Estado MS do portal OE10, que vêm colocando no ar, ao vivo, conteúdos jornalísticos diariamente em suas programações. A emissora de rádio, desde dezembro de 2017, apresenta de segunda a sexta-feira a edição do radiojornalístico CBN Campo Grande.

O portal, que é ligado ao jornal impresso O Estado de Mato Grosso do Sul, exibe, também de segunda a sexta, o Jornal da Tarde, que estreou em março de 2018. E, como são propostas recentes, inclusive pelo tempo em que as ferramentas foram disponibilizadas a todos os usuários, não há estudos registrando este cenário e as características dele em Campo Grande, MS. Importante destacar que emissoras de TV da cidade disponibilizam um ou outro programa informativo e de entretenimento da grade nas redes sociais, mas apenas estes dois exemplos destacados na pesquisa apresentam características de conteúdos jornalísticos completos, ligados aos formatos de radiojornal e telejornal, e por isso foram escolhidos para a análise.

\section{REVISÃO DE LITERATURA}

\subsection{Jornalismo na TV}

O telejornalismo sempre esteve ligado à tecnologia. O seu nascimento só foi possível graças à televisão e à necessidade de as pessoas terem acesso à informação através deste veículo eletrônico que une imagem e som. Sua chegada ao Brasil se deu na década de 1950, mais precisamente no mês de setembro. No início da televisão e do telejorna-lismo no Brasil, um conceito já esteve presente - o de mediação. Segundo Squirra (1995, p. 22), duas características eram marcantes: a herança radiofônica e a subordinação total dos programas aos patrocinadores. Seguindo a reflexão sobre o conceito, Machado (2001) comenta que o telejornalismo tem um efeito de mediação e, assim, deve ser visto:

[...] o telejornal não pode ser encarado como um simples dispositivo de reflexão dos eventos, de natureza especular, ou como mero recurso de aproximação daquilo que acontece alhures, mas antes como um efeito de mediação. A menos que nós mesmos sejamos os protagonistas, os eventos surgem para nós, espectadores, mediados através de repórteres (literalmente: aqueles que reportam, aqueles que contam o que viram), porta-vozes, testemunhas oculares e toda uma multidão de sujeitos falantes considerados competentes para construir "versões" do que acontece. (MACHADO, 2001, p. 102).

Do ao vivo ao video tape até a digitalização dos processos, o telejornalismo continua com praticamente as mesmas características. Para Machado (2001):

[...] tecnicamente falando, um telejornal é composto de uma mistura de dis-tintas fontes de imagem e som; gravações em fita, filmes, material de arqui-vo, fotografia, gráficos, mapas, textos, além de locução, música e ruídos. Mas, acima de tudo e fundamentalmente, o telejornal consiste de tomadas em primeiro plano enfocando pessoas que falam diretamente para a câmera (posição stand up), sejam elas jornalistas ou protagonistas: apresentadores, âncoras, correspondentes, repórteres, entrevistados etc. (MACHADO, 2001, p. 103-04).

Barbeiro e Lima (2002) vão além das questões técnicas e apresentam o novo jeito do telejornalismo na sociedade informacional. Para os autores, a época é de construção: 
O telejornalismo já não é o mesmo na sociedade informacional, o jornalista tem que se preparar para uma nova época em construção e não em extinção. A polêmica nos remete à discussão se o jornalismo de hoje se faz no que alguns chamam de era do conhecimento ou na era da ignorância. A era do conhecimento, segundo seus formuladores, é um conceito que descende da Revolução da Informática, da Era da Informação e do choque da Terceira Onda que varreu o mundo provocando transformações profundas. (BARBEIRO, LIMA, 2002, p. 39).

É importante ressaltar que o modo de fazer jornalismo, seja ele num veículo eletrônico ou não, ainda é o mesmo e depende de reflexão, investigação e divulgação. A barreira qualitativa não foi quebrada e faz parte da essência do jornalismo. Outra preocupação é de que o jornalista tem perdido a curiosidade, justificada, muitas vezes, pela falta de tempo ou grande quantidade de dados disponíveis. Um produto que depende tanto da subjetividade de quem o faz também a encontra em quem a ele assiste. O telespectador pode fazer várias leituras do mesmo telejornal. Machado (2001) confirma:

[...] um mesmo telejornal pode ser "lido" diferentemente por diversas comunidades de telespectadores, em função de seus valores, ideologias e estratégias perceptivas ou cognitivas. Por mais fechado que seja um telejornal, há sempre ambiguidade suficiente em forma significante, a ponto de interditar qualquer "leitura" simples e unívoca, e há também autonomia suficiente, por parte do telespectador, de modo a permitir que ele faça uma triagem do que the é despejado no fluxo televisual. (MACHADO, 2001, p. 100).

Wolton (1996, p. 57, apud MACHADO, 2001, p. 101) afirma que a significação no telejornal é função do contexto cognitivo ou sociocultural do processo de interpretação, razão por que ela sempre transborda de qualquer intenção. E este fluxo televisual pode apresentar aspectos positivos (como a abertura de possibilidades para os telespectadores) e negativos (como a superficialidade). Além da (re)mediação e da individualização, outra palavra é importante neste processo de reformulação da TV, Internet e do conteúdo. O termo é interatividade. De acordo com Silva [1999], o conceito de interação vem da física e refere-se ao comportamento de partículas cujo movimento é alterado pelo movimento de outras partículas. Multigner (1994 apud SILVA, 1999) afirma também que o conceito foi incorporado pela sociologia, pela psicologia social e, finalmente, no campo da informática transmuta-se em interatividade. De acordo com Levy (1993), até 1975, o computador era uma máquina fria e centralizadora até incorporar a tecnologia do hipertexto, criando interfaces amigáveis. Seria nesta época o período de transição para esta máquina conversacional decretado pelos informatas insatisfeitos com o conceito de interação, que buscavam o termo interatividade para dar nova dimensão ao processo pelo qual passavam.

Lemos (1997, apud THURLER, 2005) lembra que a evolução das interfaces e das formas de interatividade só foi possível com a entrada em jogo da tecnologia digital. E o que vem se chamando de interatividade ("eletrônico-digital") está diretamente ligado aos novos media digitais, podendo ser compreendida como um "diálogo entre homens e máquinas (baseadas no princípio da microeletrônica), através de uma 'zona de contato' chamada de 'interfaces gráficas', em tempo real". Barbeiro e Lima (2002) entendem o processo como qualitativo:

A Internet põe nas mãos do telespectador meios muitos mais eficazes para influir diretamente no conteúdo da programação. Ele pode, simultaneamente, ver e escrever um e-mail sobre o que está sendo transmitido. Os internautas querem consultar arquivos, ver programas já apresentados, comunicar-se com a direção da TV, propor questões para apresentadores, comentaristas e programadores. (BARBEIRO; LIMA, 2002, p. 49). 
Esta breve reflexão inicial sobre o jornalismo feito na TV, a (re)mediação e a Internet serve para refletirmos sobre as discussões dos autores a respeito do que o futuro reservava neste período de transição do veículo e de seus conteúdos. Muitas das colocações feitas já sofreram alterações bastante grandes, mas demonstram que os autores conseguiram enxergar a essência da produção de jornalismo na TV, ao mesmo tempo, que viam perspectivas para o cenário telejornalístico.

\subsection{Telejornalismo on-line, breve histórico no Brasil}

Antes de entrar na versão via Internet do telejornalismo, é importante comentar características intrínsecas do formato. De acordo com Paternostro (1999, p. 66), "em telejornalismo o texto é escrito para ser falado (pelo locutor) e ouvido (pelo telespecta-dor). Pela própria característica dos veículos eletrônicos de comunicação - a instantaneidade, o receptor deve pegar a informação de uma vez".

Neste aspecto, o da instantaneidade, o formato se iguala ao radiojornalismo, que apenas sofre pela falta da imagem. Podemos dizer que, além do texto falado do telejornalismo, a imagem também traz informação para o telespectador. Assim como a fala, a imagem, ou a organização sequencial dela num telejornal, também oferece ao telespectador um sentido e, portanto, alguma informação, independentemente do grau de escolaridade dele.

Para reforçar a ideia, Paternostro $(1999$, p. 114) diz que a informação visual "transmite mensagens através de uma linguagem que independe do conhecimento de um idioma ou da escrita por parte do receptor. A TV mostra e o telespectador vê: ele se in-forma, está recebendo a notícia e ampliando o seu conhecimento". Consequentemente, texto e imagem devem caminhar juntos no telejornalismo. A palavra-chave deve ser o equilíbrio entre as duas partes. A intenção, segundo Paternostro (1999, p. 114), é de que um não deve competir com o outro, "ou o texto tem a ver com o que está sendo mostra-do ou não tem razão de existir, perde a sua função. 0 papel da palavra é dar apoio à imagem e não brigar com ela".

A história do telejornalismo muda no fim da década de 1980, quando a informática foi incorporada. Primeiramente, com a chegada dos computadores, que agilizaram a produção, realização e exibição do formato. Segundo Paternostro (1999, p. 115), "a antiga lauda, que no telejornalismo é chamada de script, já está na tela de um terminal, e não só ela, mas todas as funções da produção de um telejornal, desde a elaboração da pauta até a exibição, estão sendo automatizadas nas redações brasileiras".

Este processo permitiu uma interligação total entre os setores da emissora de televisão e possibilidades de acesso simultâneo a todos os responsáveis pela realização do produto. Por volta de 2000, a banda larga tornou-se uma realidade no Brasil. Como consequência, surgiram os webjornais televisivos como o Jornal da Lílian (Witte Fibe), do portal Terra, e de Paulo Henrique Amorim, do portal UOL. Na mesma época, surgiu também um programa de entrevistas na internet no portal AOL, apresentado pela jorna-lista Mona Dorf. Os três com qualidade de imagem e som semelhantes ao da TV.

Em 2002, nasce outra experiência na área, a Al/TV, uma televisão realizada para exibição de conteúdo audiovisual apenas na Internet. Entre os produtos oferecidos estava o Jornal Interativo. Desta vez, sem nenhum ex-grande nome do telejornalismo feito nas TVs abertas. De acordo com o diretor da AllTV, Alberto Luchetti, a estratégia foi montar uma TV com gente jovem, 
inexperiente e com vontade de aprender fazendo. Desta forma, a Al/TV rompeu com a busca por figurões globais. O Jornal Interativo da AllTV era apresentado em 2002 por Vinícius Costa e Amanda Klein. E, mesmo com uma história recente, o jornalismo da Al/TV já obteve retorno. Em 2005, a emissora recebeu o Prêmio Esso na categoria "Melhor Contribuição ao Telejornalismo". E ao que se apresenta neste pequeno histórico do telejornalismo, tanto tradicional quanto on-line, o ao vivo, tão presente no DNA da televisão, atrelado às redes sociais, é a grande novidade na intenção de dar alcance às programações. Optou-se, nesta breve revisão de literatura, ape-nas apresentar um ponto de partida para as discussões sobre o telejornalismo praticado, em momento de transição para as redes sociais.

\subsection{Cultura da convergência e redes sociais}

Neste cenário em que toda história é contada por um número infinito de processos digitais, a convergência dos meios é palavra-chave do contexto em que estamos inseridos. Jenkins (2009) explica detalhadamente:

Por convergência, refiro-me ao fluxo de conteúdos através de múltiplas plataformas de mídia, à cooperação entre múltiplos mercados midiáticos e ao comportamento migratório dos públicos dos meios de comunicação, que vão a quase qualquer lugar em busca das experiências de entretenimento que desejam. Convergência é uma palavra que consegue definir transformações tecnológicas, mercadológicas, culturais e sociais, dependendo de quem está falando e do que imaginam estar falando. (JENKINS, 2009, p. 29).

Para Jenkins (2009), não podemos limitar o pensamento sobre convergência exclusivamente ao desenvolvimento de tecnologias e hardware que unem diversos aparelhos num único só, mas pensar também na mudança cultural que as tecnologias e as práticas da mídia provocam. O processo ocorre ainda dentro do cérebro das pessoas, no momento das interações sociais e na mudança de comportamento decorrentes desta convergência. As redes sociais aparecem como ferramentas importantes para alavancá-lo. De acordo com Recuero (2009, p. 24), a rede "é uma metáfora para observar os padrões de conexão de um grupo social, a partir das conexões estabelecidas entre os diversos atores. A abordagem de rede tem, assim, seu foco na estrutura social, onde não é possível isolar os atores sociais e nem suas conexões". As conexões oferecem aos agentes da rede social a oportunidade de contar suas histórias na convivência entre formatos/ linguagens tradicionais e as novas possibilidades ampliadas pelo contexto convergente.

\section{METODOLOGIA}

\subsection{Tipo de pesquisa}

A abordagem desta pesquisa tem abordagem qualitativa, que é bastante utilizada nas ciências sociais aplicadas. Segundo Marques et al. (2014, p. 38), esta abordagem identifica os mapas mentais que explicam a história do sujeito, retratada do jeito que ela é, porém, com uma visão mais apurada sobre o entendimento de determinada realidade. A coleta de dados para a pesquisa será desenvolvida por meio de revisão de literatura e análise de conteúdo.

De acordo com Bardin (1977, p. 42) a análise de conteúdo é caracterizada por:

Um conjunto de técnicas de análise das comunicações visando obter, por procedimentos, sistemáticos e objectivos de descrição do conteúdo de mensagens, indicadores (quantitativos 
ou não) que permitam a inferência de conhecimentos relativos às condi-ções de produção/ recepção (variáveis inferidas) destas mensagens.

A ideia é partir deste referencial metodológico para investigar as experiências de transmissão ao vivo de conteúdos jornalísticos nas redes sociais realizadas pela imprensa de Campo Grande, Mato Grosso do Sul. Primeiro, conceituar, por meio de revisão de literatura, características do telejornalismo tradicional e do telejornalismo on-line transmitido ao vivo para as redes sociais, bem como as possibilidades que elas oferecem para estes formatos informativos. Paralelamente, a ação será de identificar estas experiências para descrever processos, produtos e linguagens dos conteúdos telejornalísticos, por meio de uma análise destes conteúdos.

\subsection{Procedimento de Análise: Filtros de análise do cenário de transmissão ao vivo, no Facebook, de conteúdos jornalísticos em Campo Grande, MS}

Além das características do telejornalismo e do telejornalismo on-line, bem como dos contextos da cultura da convergência e das redes sociais, outros filtros de análise foram utilizados para avaliar o cenário das transmissões ao vivo de conteúdos jornalísticos nas redes sociais por emissoras/empresas da imprensa de Campo Grande, MS. Foram escolhidos um conteúdo sonoro/ audiovisual (CBN Campo Grande) e um audiovisual (Jornal da Tarde). Um deles foi a interatividade, descrita por Machado e Palácios (2003) como a capacidade de fazer com que o leitor/usuário se sinta mais diretamente parte do processo jornalístico (e-mails, opinião dos leitores, fóruns de discussão, chats etc.). Outros filtros foram as narrativas comuns na web definidas por Noguera Vivo (2015), especialmente as duas abaixo.

Narrativas de timelines: eixo central da história se apresenta a partir da união dos pontos cronológicos relevantes e que, por sua vez, atuam na forma de micro-histórias dentro da anterior (principal); são autônomas em relação ao significado, mas plenamente conectadas e relacionadas com todo o relato principal; normalmente ocorre em uma apresentação diferenciada com destaque para a linha do tempo. Narrativas selfie: individuais por definição. Aquelas pelas quais a marca pessoal do emissor cobra um papel determinante e a mensagem é recebida e consumida para ter o ponto de vista do emissor sobre um determinado tema; aparece, portanto, tanto a opinião quanto a informação em, sobretudo, formatos audiovisuais. (NOGUERA VIVO, 2015, p. 71-3).

A partir destes filtros serão apresentados, a seguir, os conteúdos jornalísticos elencados para esta pesquisa e, posteriormente, as considerações iniciais sobre o cenário.

\subsection{Emissoras/empresas que transmitem, ao vivo, conteúdos jornalísticos no Facebook em Campo Grande, MS}

Nesta parte do artigo, serão apresentadas as emissoras/empresas jornalísticas que transmitem ao vivo conteúdos jornalísticos pela rede social Facebook com regularidade diária em Campo Grande, MS. Primeiro será descrito um pequeno histórico das emissoras/empresas e depois os conteúdos jornalísticos analisados nesta pesquisa.

\subsubsection{Rádio CBN Campo Grande, MS}

A CBN Campo Grande entrou no ar no dia 01 de dezembro de 2017, com sede na cidade de Campo Grande, MS, na frequência FM 93,7 MHz, no processo de migra-ção da AM $1120 \mathrm{KHz}$ 
Concórdia para Frequência Modulada (FM). De acordo com Net-to (2017), a emissora faz parte do grupo RCN de Comunicação, idealizado por Rosário Congro, que tem "68 anos de atuação nos mercados jornalístico e publicitário, na Costa Leste do Estado. [...] A CBN é a 12a empresa de mídia do Grupo, entre o Jornal do Povo, rádios, mídia eletrônica, portal na internet, outdoor, indoor e a TVC-Canal 13"2.

A primeira transmissão de um programa (CBN Campo Grande) via rede social foi no dia 7 de dezembro de 2017. De segunda a sexta-feira, são transmitidos o CBN Campo Grande, das 8h30 às $11 \mathrm{~h}$, e o RCN Notícias ${ }^{3}$ das $18 \mathrm{~h}$ às $19 \mathrm{~h}$. Nos fins de sema-na, são apresentados os programas CBN Agro, CBN Motors e CBN Festas e Eventos (também exibidos desde 23 de dezembro de 2017 na página da emissora no Facebook).

\subsubsection{Jornal O Estado de Mato Grosso do Sul/OE10}

O Jornal O Estado de Mato Grosso do Sul foi fundado em 2 de dezembro de 2002 pelo empresário Jaime Vallér ${ }^{4}$. O portal OE10 foi inaugurado no dia 03 de julho de $2017^{5} \mathrm{com}$ a intenção de ampliar o conteúdo produzido pelo jornal impresso e também de colocar no ar uma TV on-line.

A primeira edição do Jornal da Tarde, da TV on-line O Estado de MS, foi ao ar das $13 \mathrm{~h} 30$ às $14 \mathrm{~h}$, ao vivo, de forma simultânea no portal e na página do Facebook da empresa, no dia 12 de março de 2018. De acordo com Yafusso $(2018)^{6}$, a TV é parte integrante dos veículos de comunicação do jornal impresso O Estado, que compreende, além da televisão, a rádio web, o jornal impresso, site O Estado Online e o Portal OE10.com.br: "inaugurada em outubro de 2017, e após um crescimento inesperado foi necessário que houvesse uma readequação na estrutura do estúdio, que é pioneira em Mato Grosso do Sul"7

\section{METODOLOGIA}

\subsection{Descrição e análise dos conteúdos jornalísticos transmitidos ao vivo no Facebook}

\subsubsection{CBN Campo Grande}

O CBN Campo Grande é um radiojornal apresentado de segunda a sexta-feira, das 8h30 às 11h, pelos jornalistas Otávio Neto e Lucas Mamédio. O conteúdo em questão que foi avaliado é uma transmissão ao vivo via página da emissora CBN Campo Grande 93,7 no Facebook, no dia 16 de março de 2018, sexta-feira, que durou 2h26min33seg.

\footnotetext{
2 Disponível em: https://www.jpnews.com.br/campo-grande/cbn-fm-lanca-modelo-inovador-de-jornalismo-emcampo-grande/104772/. Acesso em: 29 abr. 2018.

${ }^{3}$ Por questões ligadas ao horário de transmissão da Voz do Brasil, o programa RCN Notícias foi tirado do ar no dia 5 de abril de 2018.

${ }^{4}$ Disponível em: http://www.portaldemidia.ufms.br/place/o-estado-de-mato-grosso-do-sul/. Acesso em: 29 abr. 2018.

${ }^{5}$ Disponível em http://www.oe10.com.br/noticia/Dw4NDAsKCQgHBgUEAwIBANjOqbB2HY-p1eBjMJxqGYs,/ convidados_prestigiam_lanaamento_do_novo_portal_o_e10.html. Acesso em: 29 abr. 2018

${ }^{6}$ Disponível em: http://www.oe10.com.br/noticia/17070/jornal_o_estado_ms_estreia_primeira_televisao_web_ de_mato_grosso_do_sul.html. Acesso em: 29 abr. 2018.

${ }^{7}$ Apesar da informação de ser a primeira TV na internet do Estado de MS, desde 6 de abril de 2009, data do primeiro vídeo disponível no canal do YouTube, está no ar a TV Via Morena, que informa ser a primeira webtv de Mato Grosso do Sul. A emissora foi idealizada pelo radialista Sérgio Cruz e ainda transmite programação ao vivo. Disponível em: https://www.viamorena.com/. Acesso em: 29 abr. 2018.
} 
O CBN Campo Grande analisado foi composto por notas, reportagens (ao vivo e gravadas) e entrevistas (gravadas), bem como por programetes de colunistas nas áreas de agronegócio, preparação de churrasco, tecnologia, carros e criatividade. Durante a exibição do programa é possível ver os apresentadores e o estúdio/redação da emissora (Figura 01).

Figura 1- Estúdio/Redação CBN Campo Grande

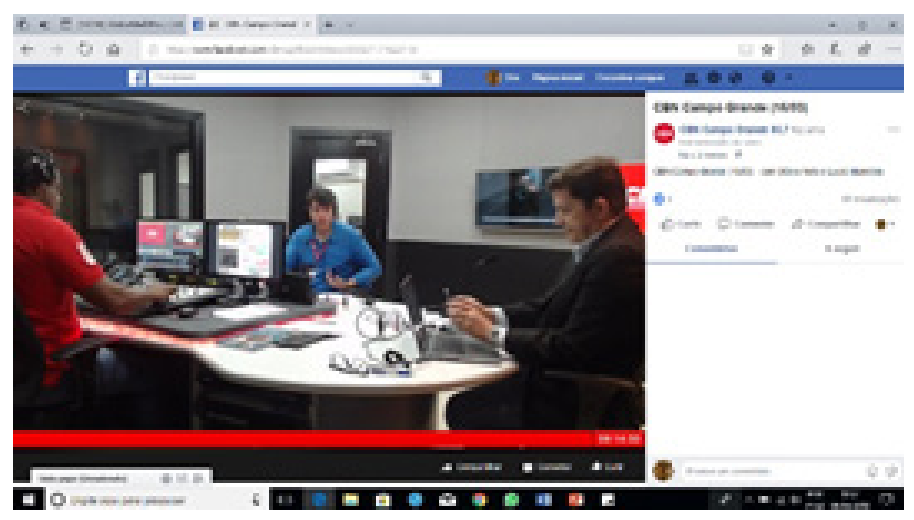

Fonte: Fhttp://facebook.com/cbncgoficial

Quando são colocadas as entrevistas, reportagens, colunistas, comerciais e a pro-gramação nacional, a logo da emissora aparece em fusão com a imagem do estúdio/redação ou totalmente em cena (Figura 02).

Figura 2 - Logo em fusão com estúdio e total

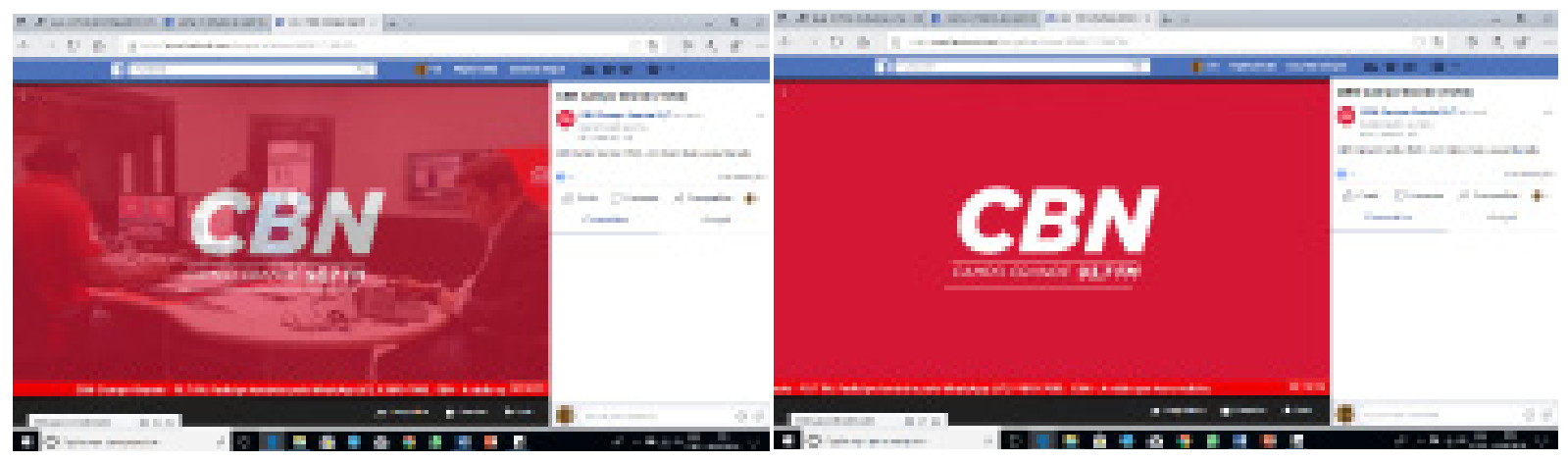

Fonte: http://facebook.com/cbncgoficial/ (Montagem do autor).

Logo no início do programa, transmitido ao vivo na página do Facebook da rá-dio, o apresentador chama a participação do ouvinte/telespectador/usuário do conteúdo jornalístico, o que é reforçado pelo gerador de caracteres (GC), assim como no caso do colunista que participa, ao vivo, da transmissão (Figura 03). 


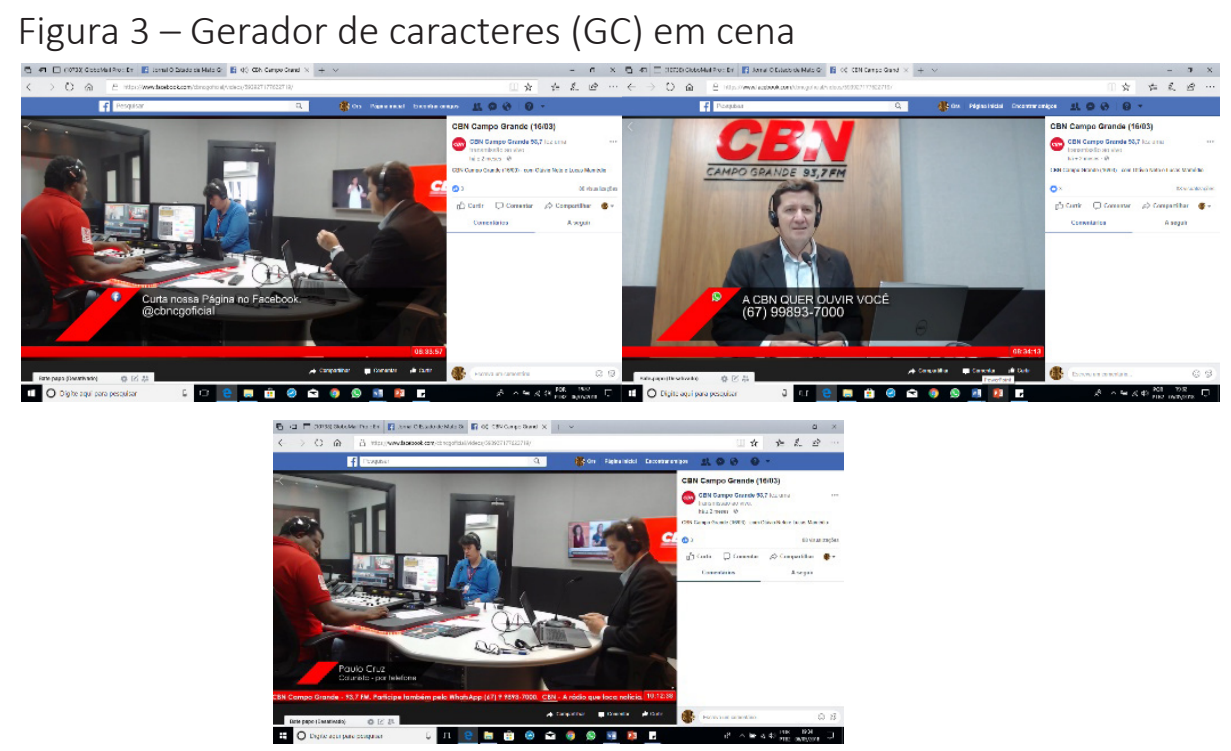

Fonte: http://facebook.com/cbncgoficial/ (Montagem do autor).

O radiojornal tem uma duração extensa, quase duas horas e meia, e neste sentido diversos conteúdos são apresentados ao longo do programa. A transmissão, até o dia 06 de maio de 2018, tinha sido visualizada 89 vezes no Facebook e recebido apenas 3 curtidas. E, mesmo chamando a participação dos ouvintes/telespectadores/usuários, em nenhum momento da transmissão eles participaram.

\subsubsection{Jornal da Tarde}

O Jornal da Tarde é um telejornal exibido de segunda a sexta-feira, das $13 \mathrm{~h} 30$ às $14 \mathrm{~h}$, pelo jornalista Ogg Ibrahim. A análise feita para este artigo refere-se ao programa transmitido ao vivo pela página do Jornal O Estado de Mato Grosso do Sul - OE10 no Facebook, sexta-feira, dia 16 de março de 2018, com duração de 27 min10seg.

O Jornal da Tarde analisado foi composto por notas lidas pelo apresentador e cobertas com imagens em movimento (que foram repetidas, ao longo da leitura) e fotos. Logo no início da transmissão, o apresentador chama a participação do telespectador/usuário (Figura 04). 
Figura 4 - Notas com vídeo e foto

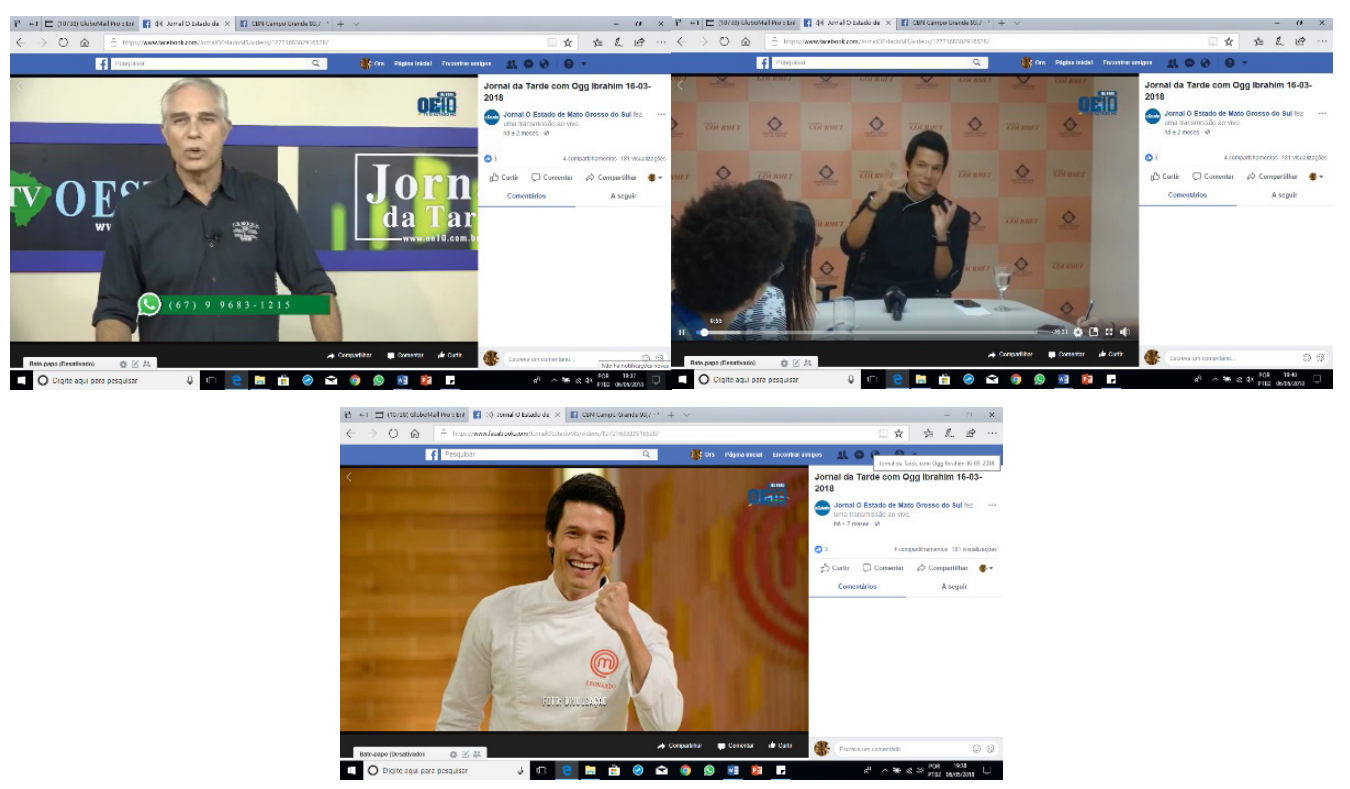

Fonte:http://facebook.com/JornalOEstadoMS/ (Montagem do autor).

Não houve, no referido telejornal, a apresentação de reportagens. Apenas uma entrevista externa ao estúdio foi colocada no ar (mas, na transmissão do Facebook, ela aparece e logo é retirada do ar). Após o único intervalo do programa, o telejornal retorna com uma entrevista de estúdio que dura 8min (última parte ao vivo do programa, quando entram os GCs da equipe de produção) (Figura 05). Logo em seguida, o apresentador chama um documentário sobre os 40 anos de Mato Grosso do Sul, de $5 \mathrm{~min}$, gravado pelo SBTMS, emissora da Capital, que encerra a transmissão.

Figura 5 - Entrevista de estúdio/encerramento com GC

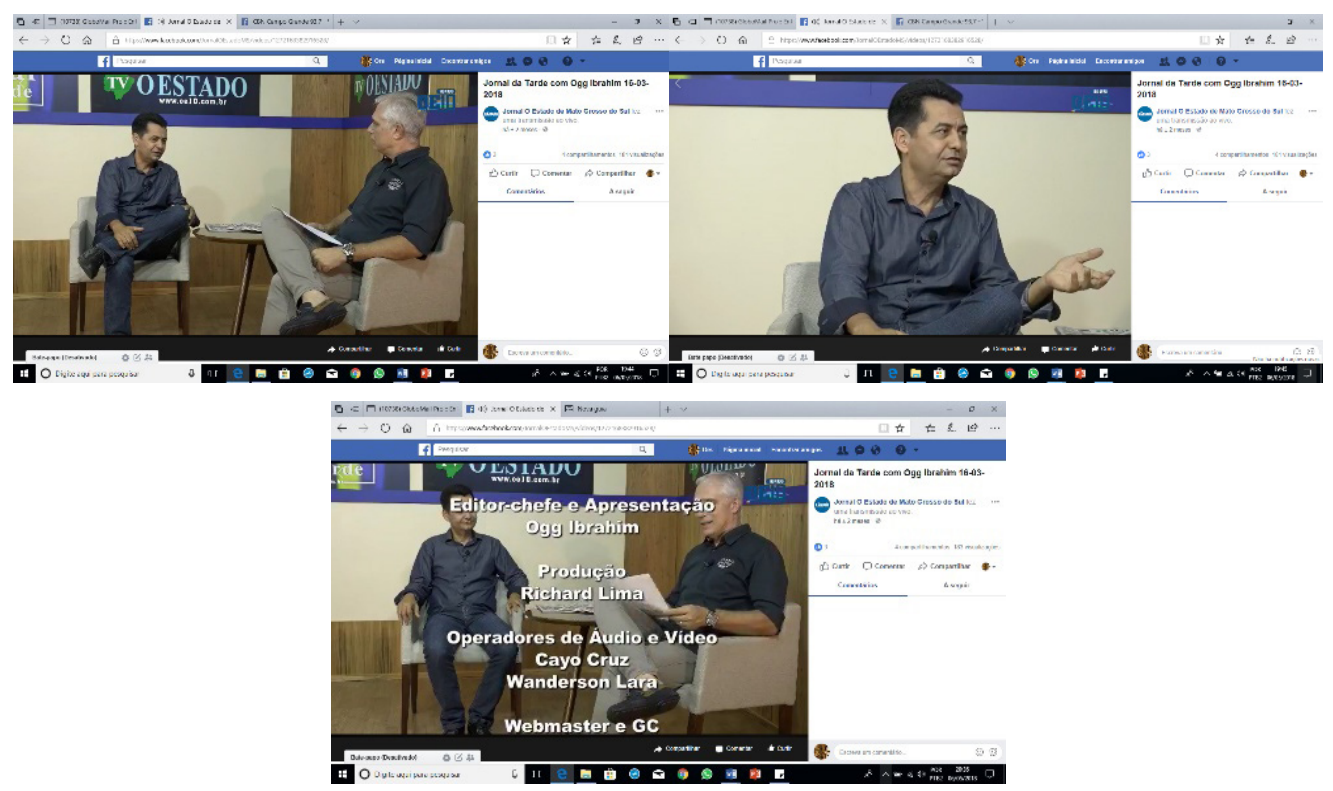

Fonte: http://facebook.com/JornalOEstadoMS/ (Montagem do autor). 
A transmissão ao vivo do Jornal da Tarde, de 16 de março de 2018, via Facebook, até o dia 06 de maio de 2018, tinha 163 visualizações, 4 compartilhamentos e também apenas 3 curtidas. Mesmo com a abertura para a participação dos telespectadores/usuários, ninguém participou.

\section{CONSIDERAÇÕES FINAIS}

A partir da análise de conteúdo feita por meio dos filtros (telejornalismo, telejornalismo on-line, interatividade e narrativas), é possível considerar que os conteúdos sonoros e audiovisuais jornalísticos transmitidos ao vivo pelas redes sociais ainda estão em processo inicial na imprensa de Campo Grande, MS. A principal rede social utilizada pelas emissoras é o Facebook e o número de acessos ainda é pequeno. Outra questão a se destacar é que pouco utilizam, nos dois casos analisados, a possibilidade de interação com os ouvintes/telespectadores/usuários da informação jornalística. Eles até são estimulados a participar, no entanto, nos dois conteúdos verificados, em nenhum momento as suas participações ou comentários são apresentados. Quanto aos quesitos do telejornalismo, o produto inicialmente sonoro (CBN Campo Grande) explora melhor os elementos visuais da transmissão, usando de caracteres gráficos para ilustrar e reforçar a informação, do que o nativo televisual (Jornal da Tarde), que abusa da leitura de conteúdo, por meio de notas, e pouco se utiliza de recursos gráficos - vemos em grande parte da transmissão apenas o apresentador e, quando da entrevista no estúdio, apresentador e entrevistado aparecem. Poucas imagens (algumas repetidas) e recursos gráficos são usados.

Com relação à Cultura da Convergência, os dois conteúdos jornalísticos apresentam as possibilidades que se abrem pelas múltiplas plataformas de mídia, nas quais uma emissora de rádio pode transmitir imagens em movimento do seu estúdio com a equipe responsável pela produção e um jornal impresso, por meio do seu portal digital, criar sua própria emissora de TV e apresentar um telejornal. As redes sociais entram nesse cenário para ampliar as conexões das duas empresas da imprensa de Campo Grande, MS, com o público que utiliza o Facebook essencialmente para ter acesso a conteúdos jornalísticos.

Na análise das narrativas, de acordo com Noguera Vivo (2015), há de se destacar a narrativa Timeline, essência da estrutura das redes sociais como recurso dos dois conteúdos analisados. Outro tipo de narrativa apresentada, que aparece também no DNA do jornalismo audiovisual, é o de Selfie, pois os apresentadores, nos dois casos, olham diretamente para as câmeras do estúdio para se comunicar com os ouvintes/telespectadores/usuários do conteúdo jornalístico. Claro que, no caso da transmissão ao vivo, via Facebook, da emissora de rádio, os olhares dos apresentadores em alguns momentos desviam-se para a leitura dos textos impressos nas folhas ou nos computadores e notebooks. O mesmo acontece com o apresentador do telejornal durante a entrevista de estúdio, mas em grande parte da leitura das notas o olhar dele é direto e em primeiro plano para o telespectador/usuário do conteúdo jornalístico, isso por conta do recurso do teleprompter (texto espelhado na tela, em frente às câmeras de estúdio).

No Brasil, o ao vivo faz parte do DNA tanto das transmissões radiofônicas quanto das televisivas (o novo é, ao mesmo tempo, o velho revisitado), e esta análise inicial demonstra que elas ainda oferecem possibilidades para os produtores de conteúdo jornalístico que têm se utilizado desta ferramenta como conexão com o público nas redes sociais. Os primeiros movimentos indicam relações entre a essência da transmissão de radiodifusão com momentos de potencialidade 
de aspectos digitais; neste sentido, os conteúdos informativos podem ganhar novos contornos com as experiências iniciais apresentadas.

\section{REFERÊNCIAS}

BARBEIRO, Heródoto; LIMA, Paulo Rodolfo. Manual de telejornalismo. Rio de Janeiro: Campus, 2002.

BARDIN, Laurence. Análise de conteúdo. Lisboa: Ed. 70, 1977.

JENKINS, Henry. Cultura da convergência. São Paulo: Aleph, 2009.

LEMOS, André. Anjos interativos e a retribalização do mundo: sobre interatividade e interfaces digitais. Lisboa, 1997. Disponível em:http://www.facom.ufba.br/ciberpesquisa/lemos/interac.html. Acesso em: 20 jun. 2017.

LEVY, Pierre. As tecnologias da inteligência: o futuro do pensamento na era da informação. Rio de Janeiro: Editora 34, 1993.

MACHADO, Arlindo. Televisão levada a sério. São Paulo: SENAC, 2001.

MACHADO, Elias; PALACIOS, Marcos (Org). Modelos do jornalismo digital. Salvador: Editora Calandra, 2003.

MARQUES, Heitor Romero; MANFROI, José; CASTILHO, Maria Augusta de; NOAL, Mirian Lange (Org.) Metodologia da pesquisa e do trabalho científico. Campo Grande: UCDB, 2014.

MULTIGNER, Gilles. Sociedad interactiva o sociedad programada? In: FUNDESCO (Org.). Apuntes de la sociedad interactiva Cuenca. Espanha: UIMP, 1994.

NETO, Otávio. Rádio CBN lança modelo inovador de jornalismo em Campo Grande. JPNews. Três Lagoas. 02 Dez. 2017. Disponível em: https://www.jpnews.com.br/campo-grande/cbn-fm-lanca-modelo-inovadorde-jornalismo-em-campo-grande/104772 / Acesso em: 29 Abr. 2018.

NOGUERA VIVO, José Manuel. Todos, todo: manual de periodismo, participación y tecnología. Barcelona: Oberta UOC Publishing, 2015.

PATERNOSTRO, Vera Íris. O texto na TV: manual de telejornalismo. Rio de Janeiro: Campus, 1999.

RECUERO, Raquel. Redes sociais na internet. Porto Alegre: Sulina, 2009.

SILVA, Marco. O que é interatividade. [199-]. Disponível em: http://www.senac.br/informativo/BTS/242/ boltec242d.htm. Acesso em: 20 jun. 2017.

SQUIRRA, Sebastião. Aprender telejornalismo: produção e técnica. São Paulo: Brasiliense, 1995.

THURLER, Larriza. TV na Internet: reflexões sobre remediação e interatividade. Rio de Janeiro: Intercom, 2005.

WOLTON, Dominique. Elogio do grande público - uma teoria crítica da televisão. São Paulo: Ática, 1996.

YAFUSSO, Fernanda. Jornal O Estado estreia primeira televisão web de Mato Grosso do Sul. O Estado de MS-OE10. Campo Grande, 13 mar. 2018. Disponível em:http://www.oe10.com.br/noticia/17070/jornal_o_ estado_ms_estreia_primeira_televisao_web_de_mato_grosso_do_sul.html. Acesso em: 29 abr. 2018. 


\section{Sobre os autores:}

Oswaldo Ribeiro da Silva: Pós-doutorado pelo Programa Nacional de Pós-Doutorado (PNPD/ CAPES) no Programa de Pós-Graduação em Comunicação da Universidade Federal de Mato Grosso do Sul (PPGCom/UFMS). Doutorado em Educação (UFMS) com tese no Campo do Jornalismo pelo Programa de Pós-Graduação em Educação (PPGEdu). Mestrado em Ciência da Informação pela Universidade de Brasília (UNB). Graduação em Jornalismo pela UFMS. Professor dos cursos de Jornalismo, Publicidade e Propaganda e Rádio e TV na UCDB. Jornalista/ Editor de Telejornais e Radiojornais nas principais emissoras de Campo Grande, MS. E-mail: oswaldoribeiro@ucdb.br, Orcid: http://orcid.org/0000-0002-8366-8190

Marcelo Vicente Cancio Soares: Pós-doutorado em Ciências da Comunicação na Universidade Autônoma de Barcelona. Doutorado e Mestrado em Ciências da Comunicação pela Escola de Comunicação e Artes da Universidade de São Paulo. Professor efetivo da Universidade Federal de Mato Grosso do Sul, lotado no Departamento de Comunicação Social/Jornalismo do Centro de Ciências Humanas e Sociais. E-mail: marcelo.cancio@ufms.br, Orcid: http://orcid.org/0000-0002-3879-4200 
